\title{
PENINGKATAN KREATIVITAS GURU MELALUI PELATIHAN MODEL PEMBELAJARAN SAINTIFIK BERBASIS PANTAI DAN LAUT DI DAERAH PESISIR PANTAI SIDOARJO
}

\author{
Oleh: \\ Bambang Suratman', Jun Surjanti, Harti ${ }^{3}$, Raya Sulistyowati4 ${ }^{4}$ Siti Sri Wulandari5 \\ 1,2,3,4,5 Universitas Negeri Surabaya \\ Bambang.1212@yahoo.com
}

\begin{abstract}
Abstrak
Tujuan kegiatan ini adalah meningkatan kreativitas guru kewirausahaan SMA dan SMK dalam membuat RPP berbasis pantai dan laut khususnya di daerah pesisir pantai dan laut Sidoarjo. Pelatihan model pembelajaran saintifik berbasis pantai dan laut ini memiliki manfaat bagi guru untuk meningkatkan kemampuan pedagogik guru-guru kewirausahaan SMA dan SMK se-Sidoarjo. Melalui kegiatan tersebut, guru kewirausahaan dapat mengaitkan antara materi yang diajarkan dengan situasi dunia nyata siswa. Selanjutnya, siswa pun dapat membuat hubungan antara pengetahuan yang dimilikinya dengan penerapannya dalam kehidupan mereka sebagai anggota keluarga dan masyarakat. Peran guru kewirausahaan dituntut supaya mampu meningkatkan kreativitasnya dalam membuat RPP yang berbasis pantai dan laut supaya dapat mengembangkan potensi sumber daya alam pantai dan laut di daerahnya masing-masing, dan mampu menciptakan produk inovatif dari sumber daya hasil pantai dan laut tersebut.
\end{abstract}

Kata Kunci: kreativitas guru, pembelajaran saintifik, wilayah pesisir laut

\begin{abstract}
The purpose of this activity is increasing the creativity of high school (including vocational school) teacher teching entrepreneurship to create lesson plans based on the beach and the sea, especially in the coastal areas and the sea of Sidoarjo. Learning model-based scientific training and sea coast has benefits for teachers to improve entrepreneurial pedagogical high school teachers and SMK in Sidoarjo. Through these activities, teachers can entrepreneurial links between what is taught to the students real-world situations. Furthermore, students can make a connection between knowledge possessed by the application in their lives as members of the family and society. The role of entrepreneurship teachers are required to be able to improve their creativity in making lesson plans based on the beach and sea in order to develop the potential of natural resources and sea shore in their respective regions, and are able to create innovative products of the resources of the sea beach and the results.
\end{abstract}

Keywords: Teacher's creativity, scientific learning, coastal areas

\section{PENDAHULUAN}

Salah satu program Nawa Cita yang terkait dengan pendidikan ada pada masalah kemerosotan mental. Upaya mengatasi kemerosotan mental dalam Nawa Cita ada pada poin ke-8. Program tersebut menjelaskan bahwa peran utama pendidikan pada saat ini harus berhulu pada revolusi karakter bangsa melalui kebijakan penataan kembali kurikulum pendidikan nasional dengan mengedepankan aspek pendidikan kewarganegaraan dan secara proporsional memberikan aspek pendidikan sejarah pembentukan bangsa, nilai-nilai patriotisme dan cinta Tanah Air, semangat bela negara dan budi pekerti di dalam kurikulum pendidikan Indonesia.
Pembelajaran yang dapat diterapkan dalam kehidupan sehari-hari juga merupakan tuntutan saat ini. Untuk itu, peranan guru dalam mengembangkan pembelajaran sangat berperan dalam pembentukan karakter sebagai upaya revolusi moral. Guru dituntut kreatif dalam pembelajaran sejalan dengan amanah kurikulum 2013. Hasil UKG guru yang merupakan nilai kemampuan pedagogik/pembelajaran guru belum optimal. Hal ini menjadi indikator bahwa kreativitas pembelajaran guru belum optimal. Data kementrian menunjukkan bahwa nilai UKG masih rendah rata-rata UKG nasional yaitu kemampuan pedagogik dan professional sebesar 53,02, sedangkan KKM yang ditargetkan pemerintah adalah 55.00. Jika dipilah, rerata nilai UKG untuk kompetensi 
profesional 54,77, sedangkan nilai rata-rata kompetensi pedagogik 48,94.

Kabupaten Sidoarjo dalam capaian pembelajaran tertinggi baru sampai pada penerapan pembelajaran berbasis adiwiyata dimana sekolah menata pembelajaran dan lingkungan belajarnya sedemikian rupa agar siswa dapat berperilaku tanggung jawab terhadap lingkungan (ekosistem). Lingkungan yang diminiaturkan dalam adiwiyata adalah lingkungan darat. Hal ini tentu belum mencakup lingkungan yang berbatasan dengan laut (pesisir/pantai) sebagaimana beberapa kecamatan di Sidoarjo yang langsung berbatasan dengan laut, yaitu Selat Madura. Hasil komoditas masyarakat Sidoarjo ini merupakan penghasil perikanan, diantaranya ikan, udang, dan kepiting. Bahkan perikanan menjadi salah satu sektor perekonomian Sidoarjo selain industri dan jasa. Perikanan menjadi mata pencaharian utama penduduk Sidoarjo yang tinggal dan hidup di wilayah pesisir.

Berbagai kegiatan pemberdayaan yang dilakukan di wilayah pesisir terhadap subsektor perikanan laut yang merupakan sumber mata pencaharian dan kesejahteraan bagi 13,6 juta orang, dan secara tidak langsung mendukung kegiatan ekonomi bagi sebagian besar penduduk Indonesia yang bermukim di wilayah pesisir (Dahuri dkk., 1996). Menurut Pulukadang dan Sya'roni dalam Yuliastutik (2003), sebagai "tapal batas terakhir", laut menawarkan berbagai peluang usaha untuk dikembangkan, terutama untuk masa-masa mendatang. Untuk itu, masyarakat Sidoarjo harus kreatif dalam memenuhi kebutuhan dengan cara yang tepat dan benar agar kepentingan kepentingan peningkatan kesejahteraan tidak mengorbankan kelestarian sumber daya alam dan lingkungan pesisirnya.

Tidak jarang aktivitas ekonomi masyarakat pesisir justru menimbulkan dampak negatif (Suryaonline.com, 22 September 2013; Bappeda Jatim, 8 Maret 2011). Untuk itu, potensi masyarakat di wilayah pesisir ini masih terus ditingkatkan. Pengembangan potensi laut dapat dilakukan melalui peningkatan kreativitas penduduk. Kreativitas penduduk sendiri dapat ditingkatkan melalui peningkatan pengetahuan dan ketrampilan di jalur pendidikan.

Hal ini karena pendidikan berperan sebagai wadah untuk proses belajar mengajar pada akhirnya akan menghasilkan kemampuan siswa yang mencakup pengetahuan, sikap, dan keterampilan.
Purwanto (2010:45) berpendapat bahwa hasil belajar adalah perubahan yang mengakibatkan manusia berubah dalam sikap dan tingkah lakunya. Pendidikan diharapkan dapat mengedukasi masyarakat pesisir untuk lebih kreatif dalam mengolah dan memanfaatkan hasil laut sehingga dapat meningkatkan pendapatan penduduk. Kabupaten Sidoarjo masih membutuhkan program yang dapat mengangkat potensi perekonomian keluarga melalui jalur pendidikan. Pengembangan potensi ekonomi laut yang sekaligus mempercepat revolusi mental masyarakat pesisir membutuhkan peran penting guru kewirausahaan. Penanaman sikap untuk menjaga eksistensi laut dapat dilakukan dengan cara meningkatkan kreativitas guru kewirausahaan dalam pembelajaran agar menyampaikan pesan untuk pemanfaatan laut dengan cara yang baik agar eksistensi pantai dan lautnya tetap terjaga. Pengambilan manfaat ekonomi tanpa mengabaikan kelestarian pantai yang telah diambil hasilnya juga harus terjaga. Semua ini dapat dilakukan guru dengan menerapkan berbagai pendekatan pembelajaran dengan obyek pantai dan laut. Pendekatan pembelajaran ini dikenal dengan pembelajaran kontekstual.

Pembelajaran konteksual atau contextual learning merupakan pembelajaran dengan cara memanfaatkan pantai dan laut untuk obyek/tema pembelajaran. Sesuai dengan pendapat Wina (2006:253) bahwa pendekatan kontekstual (contextual teaching and learning) adalah suatu strategi pembelajaran yang menekan kepada proses keterlibatan siswa secara penuh untuk dapat menemukan materi yang dipelajarinya dan menghubungkannya dengan situasi kehidupan nyata. Pendekatan ini dapat membantu guru maupun siswa dalam mengaitkan materi dengan kenyataan. Guru dapat mengaitkan antara materi yang diajarkan dengan situasi dunia nyata siswa. Selanjutnya, siswa pun dapat membuat hubungan antara pengetahuan yang dimilikinya dengan penerapannya dalam kehidupan mereka sebagai anggota keluarga dan masyarakat. Penerapan K-13 bukan kendala penerapan pembelajaran kontekstual dalam kerangka kurikulum K-13 yang berbasis pada pendekatan saintifik. Prinsipprinsip kontekstual tetap dapat diimplementasikan dalam model-model pembelajaran berbasis saintifik seperti discovery learning, inquiry learning, Problem Based Learning (PBL) maupun Project Based 
Learning (PjBL). Bagaimana cara penerapan prinsip pembelajaran kontekstual dalam kerangka pendekatan saintifik ini perlu diberikan kepada guru SMA dan SMK, yaitu guru di jenjang pendidikan menengah yang menghadapi siswa usia kerja.

Selama ini SMA dan SMK di Sidoarjo rata-rata masih menggunakan RPP yang berbasis adiwiyata dimana sekolah menata pembelajaran dan lingkungan belajarnya sedemikian rupa agar siswa dapat berperilaku tanggung jawab terhadap lingkungan (ekosistem). Lingkungan yang diminiaturkan dalam adiwiyata adalah lingkungan darat, padahal wilayah Sidoarjo tidak hanya terdiri dari daratan saja juga terdapat daerah pesisir pantai dan laut yang bisa dioptimalkan sebagai sarana dan media pembelajaran khususnya di wilayah Kec.Sedati, Candi dan Porong. Disinilah peran guru kewirausahaan dituntut supaya mampu meningkatkan kreativitasnya dalam membuat RPP yang berbasis pantai dan laut sehingga dapat mengembangkan potensi sumber daya alam pantai dan laut di daerahnya masing-masing, dan mampu menciptakan produk inovatif dari sumber daya hasil pantai dan laut tersebut. Pembelajaran yang berbasis pantai dan laut ini akan mempercepat revolusi mental di masyarakat pesisir dalam pengoptimalan potensi ekonominya.

Akhirnya, guru kewirausahaan yang mempunyai peran penting dalam pembentukan sikap bertanggungjawab pada lingkungan pantai dan laut untuk meningkatkan potensi ekonomi Sidoarjo ke depan. Guru kewirausahaan diharapkan memiliki kreativitas untuk mengembangkan perangkat pembelajaran melalui model pembelajaran yang digunakan di kelas mereka. Pengetahuan guru dalam membuat Rencana Pelaksanaan Pembelajaran (RPP) berbasis pantai/laut ini menjadi faktor kunci tumbuhnya kreativitas pembelajaran. Guru yang kreatif akan dapat menghubungkan materi dengan keadaan/kenyataan yang dihadapi siswa siswa, menciptakan pembelajaran yang menyenangkan bagi siswa, meningkatkan kualitas pencapaian tujuan pembelajaran, dll.

Kreativitas guru dapat ditingkatkan melalui pemberian pelatihan model pembelajaran berbasis pantai dan laut. Untuk mendukung peningkatan kreativitas guru dalam pembelajaran di wilayah pesisir pantai Sidoarjo, maka Unesa memberikan pelatihan metode/model pembelajaran dengan objek/tema pantai dan laut agar dapat dimanfaatkan guru untuk peningkatan mutu pembelajaran di masa yang akan datang. Unesa sebagai Lembaga Pendidikan Tinggi Keguruan (LPTK) khususnya Fakultas Ekonomi mempunyai sumber daya manusia yang dibutuhkan oleh masyarakat pesisir Sidoarjo. Kegiatan pelatihan model pembelajaran yang diberikan oleh ahli pendidikan dalam bidang ekonomi diharapkan mitra, yaitu guru kewirausahaan SMA dan SMK di Kabupaten Sidoarjo diharapkan memberikan pengetahuan dan ketrampilan pedagogik. Peningkatan kreativitas guru dalam merancang Rencana Pelaksanaan Pembelajaran (RPP) menjadi tujuan akhir kegiatan Iptek bagi Masyarakat (IbM) ini.

\section{METODE PELAKSANAAN}

Metode pelaksanaan kegiatan ini terdiri dari tiga hal utama, yaitu: a) permasalahan prioritas guru kewirausahaan yang menjadi mitra kegiatan belum pernah menerapkan $\mathrm{K}$ 13 model pembelajaran berbasis pantai dan laut untuk mengatasi dampak negative akibat aktivitas ekonomi serta mengoptimalkan potensi di kawasan pesisir Sidoarjo, b) prosedur kerja yang berupa pelatihan dan praktik model pembelajaran berbasis pantai dan laut. Adapun materi model pembelajaran yang dibuat dapat berupa project based learning, problem based learning, discovery learning, role playing, dan kooperatif learning. Kemudian guru kewirausahaan praktek membuat model RPP berbasis pantai dan laut dan yang terakhir simulasi model RPP berbasis pantai dan laut. c) jenis luaran yang dihasilkan yaitu sintak pembelajaran sebagai embrio RPP berbasis pantai dan laut. Sintak yang dihasilkan mengandung spesifikasi aktivitas berupa mengamati, menanya, mengumpulkan data, mengasosiasi dan mengkomunikasikan.

Adapun prosedur kerja kegiatan pelatihan ini dirinci dalam beberapa kegiatan yaitu: a) penyampaian materi teori belajar, b) materi dan contoh metode dan model pembelajaran (umum) dengan saintifik, c) simulasi model pembelajaran berbasis pantai dan laut, d) praktek analisis model berupa analisis kebutuhan peserta didik dan analisis $\mathrm{KI}$ dan $\mathrm{KD}, \quad$ e) praktek mendesain model pembelajaran berbasis pantai dan laut serta membuat draft model dalam kertas buram, f) praktek membuat model pembelajaran berbasis pantai dan laut dalam sebuah RPP, 
g) evaluasi model pembelajaran berbasis pantai dan laut berupa evaluasi identitas RPP, evaluasi pedagogic RPP, evaluasi prinsip pembelajaran kontektual dalam RPP dan evaluasi basis pantai dan laut dalam model pembelajaran di RPP. Dalam proses evaluasi peserta diminta mengirimkan hasil akhir pengembangan model dan angket melalui email panitia, dan h) pengiriman sertifikat peserta melalui pos.

\section{HASIL DAN PEMBAHASAN}

Pelaksanaan workshop untuk pelatihan guru kewirausahaan SMK dan SMA Se-Sidoarjo dilaksanakan pada hari Sabtu, 06 Agustus 2016, adapun hasil kegiatan workshop tersebut antara lain:

\section{Workshop Pembelajaran Berbasis Pantai dan Laut Dalam Kelas}

Kegiatan ini melibatkan nara sumber sebagai pakar pendidikan dalam memberikan informasi singkat, dan diskusi untuk memberikan wawasan seputar kurikulum dan nawacita ke peserta didik melalui pendekatan saintifik, berbasis pantai dan laut, sedangkan anggota tim yang lainnya, mengamati proses diskusi yang terjadi, serta menuliskan dalam suatu jurnal. Berdasarkan pengamatan, para guru sangat antusias mengikuti workshop, berdiskusi, dan menyusun RPP berbasis pantai dan laut ini. Para guru merasa leluasa menyampaikan berbagai persoalan terkait dengan analisis $\mathrm{KI}$ dan KD Kewirausahaan pada Kurikulum Nasional, dan pengembangan RPP berbasis pantai dan laut. Dengan antusiame yang tinggi diharapkan kreativitas guru semakin meningkat dalam mengembangkan pembelajaran dengan pendekatan saintifik dengan memanfaatkan sumber daya alam pesisir pantai dan laut yang ada di daerah Sidoarjo. Salah satu usaha yang dilakukan dengan mengembangkan tema yang dekat dengan kehidupan siswa. Panitia memberikan panduan penyusunan serta contoh silabus dan RPP yang disajikan dalam sebuah lampiran. Hasil kuisioner guru kewirausahaan dari workshop ini menyatakan selama ini telah menggunakan tema pantai dan Laut dalam pembelajaran sesuai tema pantai dan laut sebesar $50 \%$. Pembelajaran yang dikembangkan telah mengkontekstualkan pantai dan laut dalam tujuan pembelajaran, kegiatan pembukaan, keiatan inti, kegiatan penutup, materi/sumber belajar, alat dan bahan belajar sebesar $65 \%$, dan sebesar $40 \%$ menyatakan bahwa pembelajaran yang dikembangkan belum dikontekstualkan dalam pantai dan laut.

\section{Praktik Pengembangan Model Pembelajaran Berbasis Pantai dan Laut Secara Out Class}

Dalam kegiatan workshop out class para guru menganalisis kebutuhan peserta didik dan analisis $\mathrm{KI}$ dan $\mathrm{KD}$, setelah itu guru meningkatkan kreatifitasnya dalam mendesign model pembelajaran berbasis pantai dan laut. Guru selanjutnya mengembangkan model pembelajaan berbasis pantai dan laut dalam sebuah RPP. Tahap berikutnya, RPP yang sudah selesai dibuat dikirim via email paling lambat tanggal 15 Agustus 2016 pukul 24.00WIB ke alamat email panitia.

\section{Evaluasi Pengembangan Model Pembelajaran Berbasis Pantai dan Laut}

Dalam tahapan ini RPP guru berbasis pantai dan laut dievaluasi oleh panitia. Evaluasi Model Pembelajaran Berbasis Pantai dan Laut memiliki criteria penilaian sebagai berikut a.) Evaluasi identitas RPP, b) Evaluasi pedagogik RPP, c) Evaluasi Prinsip Pembelajaran Kontekstual dalam RPP, dan d) Evaluasi Basis Pantai \& Laut dalam Model Pembelajaran di RPP. Setelah semua RPP dievaluasi dan diberi masukan panitia mengirim ke peserta workshop untuk diperbaiki kembali sesuai saran dan masukan panitia. Ketika guru telah selesai menyelesaikan revisi RPP maka mengirimkan RPP tersebut via email kepada panitia, dan panitia mengirimkan sertifikat workshop pembelajaran berbasis pantai dan laut kepada peserta.

\section{Hasil Observasi Pengembangan RPP}

Observasi dilakukan dalam proses pengembangan RPP berbasis pantai dan laut oleh para guru kewirausahaan. Hasil Penilaian Pembuatan RPP guru berbasis pantai dan laut sebagai berikut nilai terendah 80 pada level Basis Pantai dan laut. Kemudian pada kemampuan pedagogi. mendapat nilai 97, dan nilai tertinggi 100 pada identitas RPP dan prinsip konstektual para guru. Lebih jelasnya dilihat pada Gambar 1. 


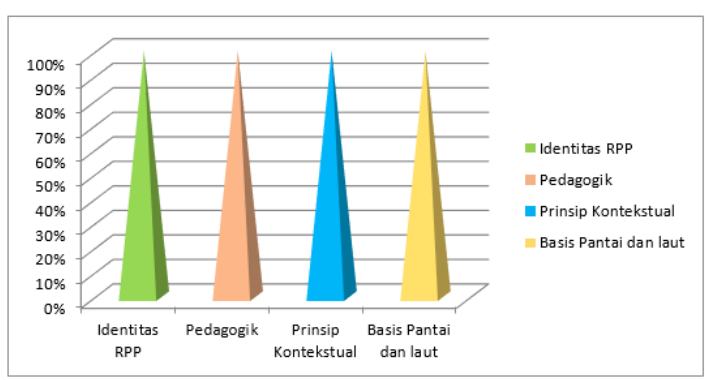

Gambar 1. Grafik Hasil Nilai Pembuatan RPP Berbasis Laut Nilai

\section{Pembahasan}

Respon guru terhadap kegiatan workshop pembelajaran berbasis pantai dan laut ini secara umum sangat positif. Antusiame peserta sangat tinggi. Para guru menilai bahwa kegiatan ini sangat relevan dan sesuai dengan kebutuhan, yaitu kebutuhan meningkatkan jiwa entreuprenership atau kewirausahaan di kalangan guru kewirausahaan sekaligus menerapkannya di dalam kelas sehingga berkonstribusi menciptakan wirausahawan baru dari peserta didik setelah selesai menamatkan bangku sekolah. Siswa sudah dibekali guru bagaimana memanfaatkan dan mengolah sumber daya pantai dan laut di daerah masing-masing. Seperti yang disampaikan Purwanto (2010:45) bahwa hasil belajar adalah perubahan yang mengakibatkan manusia berubah dalam sikap dan tingkah lakunya. Pendidikan diharapkan dapat mengedukasi masyarakat pesisir untuk lebih kreatif dalam mengolah dan memanfaatkan hasil laut sehingga dapat meningkatkan pendapatan penduduk. Pembelajaran konteksual atau contextual learning merupakan pembelajaran dengan cara memanfaatkan pantai dan laut untuk obyek/tema pembelajaran. Sesuai dengan pendapat Wina (2006:253) bahwa pendekatan kontekstual (contextual teaching and learning) adalah suatu strategi pembelajaran yang menekan kepada proses keterlibatan siswa secara penuh untuk dapat menemukan materi yang dipelajarinya dan menghubungkannya dengan situasi kehidupan nyata. Pendekatan ini dapat membantu guru maupun siswa dalam mengaitkan materi dengan kenyataan. Disinilah peran kreativitas guru kewirausahaan khususnya di kabupaten Sidoarjo dalam merancang model RPP berbasis pantai dan laut sehingga potensi local pantai melalui pembelajaran saintifik. Hasil dari pembelajaran saintifik membuat siswa mendapatkan pengalaman yang bermakna setelah menamatkan jenjang sekolah menengah atas maupun sekolah menengah kejuruan dan mampu memperbaiki perekonomian keluarga melalui jalur pendidikan.

Analisis materi KI dan KD Kewirausahaan sudah mengacu pada Permendikbud no.81A tahun 2013 tentang implementasi kurikulum pada sekolah formal mulai dari SD sampai SMA/ SMK. Serta mengacu pada stándar proses, yaitu Permendikbud No. 65 Tahun 2014 dengan teknik penyajian yang luwes, humor, dan menarik. Dengan kegiatan ini para guru dapat meng-upgride diri meningkatkan pemahamannya berkaitan dengan model pembelajaran berbasis pantai dan laut melalui pendekatan scientifik. Beberapa di antara guru memang sudah pernah mengikuti pelatihan, akan tetapi guru merasa sangat binggung. Oleh karena itu para guru dituntut untuk sekreatif mungkin dalam mengembangkan model kewirausahaan berbasis pantai dan laut. Hal ini sejalan dengan pemikiran Pulukadang dan Sya'roni dalam Yuliastutik (2003), sebagai "tapal batas terakhir", laut menawarkan berbagai peluang usaha untuk dikembangkan, terutama untuk masa-masa mendatang. Masyarakat Sidoarjo harus kreatif dalam memenuhi kebutuhan dengan cara yang tepat dan benar agar kepentingan kepentingan peningkatan kesejahteraan tidak mengorbankan kelestarian sumber daya alam dan lingkungan pesisirnya. Dengan pendidikan, dapat dilakukan penanaman sikap mental dan karakter positif untuk mengembangkan potensi ekonomi laut pesisir Sidoarjo. Jika hal ini tercapai maka secara langsung Sidoarjo pun telah mewujudkan percepatan pencapaian Nawa Cita yang dicanangkan pemerintah.

\section{SIMPULAN DAN SARAN}

Workshop pembelajaran berbasis pantai dan laut mampu meningkatkan kemampuan dan pengetahuan guru kewirausahaan dalam pembuatan model pembelajaran berbasis pantai dan laut dalam bentuk RPP yang baik. Rata-rata kualitas RPP yang dikembangkan guru kualitasnya baik.

Sebaiknya para guru kewirausahaan senantiasa meningkatkan kemampuan pedagogik, meningkatkan kreativitasnya dalam menggunakan model-model pembelajaran dan metode pembelajaran yang interaktif dengan pendekatan 
konstektual sehingga pembelajaran menjadi bermakna bagi siswa.

\section{DAFTAR PUSTAKA}

Abidin, Yunus. 2014. Desain Sistem Pembelajaran Dalam Konteks Kurikulusm 2013. Bandung: Refika Aditama.

Bappeda Jatim. 8 Maret 2011. Pesisir Sidoarjo Marak Dikapling, Berita, (Online), dalam http://bappeda.jatimprov.go.id/2011/0 3/08/pesisir-sidoarjo-marakdikapling/, diakses tanggal 14 Maret 2016.

Dahuri, dkk. 1996. Pengelolaan Sumberdaya Wilayah Pesisir dan Lautan Secara Terpadu. Jakarta: Pradya Paramita.

Direktorat Pembinaan SMP. Direktorat Jenderal Manajemen Pendidikan Dasar Dan Menengah. Departemen Pendidikan Nasional .2006. Pengembangan Model Pembelajaran yang Efektif.

Purwanto. 2010. Evaluasi Hasil Belajar. Yogyakarta: Pustaka Pelajar.
Republika.com. 31 Desember 2015. Guru Yogyakarta raih Nilai UKG Tertinggi, Berita, (Online), dalam http://www.republika.co.id/berita/kora n/didaktika/ 15/12/31/o07q886-guruyogyakarta-raih-nilai-ukg-tertinggi, diakses tanggal 20 Maret 2016.

Simamora, Roymond H. (2009). Buku Ajar Pendidikan dalam Keperawatan. JakartaEGC

SuryaOnline.com. 22 September 2013. Hutan Mangrove Di Pesisir Timur Sidoarjo Rusak, Berita, (Online), dalam http://surabaya.tribunnews.com/2013/ 09/22/ hutan-mangrove-di-pesisirtimur-sidoarjo-rusak, diakses tanggal 14 Maret 2016.

Wina Sanjaya. 2006. Strategi Pembelajaran Berorientasi Standar Proses Pendidikan. Jakarta: Kencana.

Yuliastutik, E. 2003. Pengaruh Status Sosial Terhadap Pola Konsumsi Pangan Keluarga Nelayan. Skripsi. Jember: Universitas Jember. 